\title{
FACTORS ASSOCIATED WITH SEASONAL INFLUENZA IMMUNIZATION IN PEOPLE WITH CHRONIC DISEASES
}

\section{FAKTORI POVEZANI SA IMUNIZACIJOM PROTIV SEZONSKOG GRIPA MEĐU OSOBAMA SA HRONIČNIM BOLESTIMA}

\author{
Slađana Arsenović ${ }^{1}$ Tatjana Gazibara ${ }^{2}$
}

${ }^{1}$ Institut za javno zdravstvo Republike Srpske, Regionalni centar Foča, Foča, Republika Srpska, Bosna i Hercegovina

${ }^{2}$ Institut za epidemiologiju, Univerzitet u Beogradu, Medicinski fakultet, Beograd, Srbija

Correspondence: tatjanagazibara@yahoo.com

\begin{abstract}
Annually, at a global level, 3 to 5 million people present severe clinical forms of seasonal influenza and up to 650000 people die of influenza-related complications. People with chronic diseases, such as cardiovascular, pulmonary, renal, hepatic, neurologic, hematologic and metabolic diseases or those reciveing immunosuppressive therapy, constitute a high-risk population group for the development of influenza-related complications, more severe clinical course and poorer health-related outcomes. Due to all of the above, people with chronic diseases are of high priority to receive the influenza vaccine. Immunization represents the key strategy to prevent influenza both in terms of effectiveness and health care costs. Based on the World Health Organization (WHO) recommendations, adequate seasonal influenza immunization coverage among people with chronic diseases is set at $75 \%$. However, few countries achieve this threshold. Understanding predictive factors of vaccination, at different levels of health care delivery (such as individuals, service providers, health policy), is essential to secure acceptance of influenza immunization and achieve the recommended level of vaccination coverage. In this mini review, all the available evidence regarding seasonal influenza vaccination coverage is summarized, alongside factors associated with vaccine uptake in people with chronic diseases as a whole, as well as according to specific diseases such as: cardiovascular and pulmonary disorders, diabetes and cancer. Based on the reviewed empirical evidence, a wide spectrum of factors associated with immunization against influneza was found in people who have chronic diseases. Although diverse, these factors can be systematized into 4 distinctive groups: socio-demographic characteristics, individual attitudes and beliefs, health promoting behaviors and factors related to the health care system. Further efforts are needed to improve the seasonal influenza vaccination coverage. The immunization strategy needs to include the health care system and the community to support people with chronic diseases to continously accept the influenza vaccine.
\end{abstract}

Keywords:

influenza, immunization, chronic diseases, predictors 


\section{Sažetak}

Svake godine od 3 do 5 miliona ljudi u svetu ima teške kliničke oblike sezonskog gripa, a do 650.000 umire od komplikacija povezanih sa gripom. Osobe sa hroničnim bolestima, poput kardiovaskularnih, plućnih, bubrežnih, jetrenih, neuroloških, hematoloških, metaboličkih bolesti ili osobe koji primaju imunosupresivnu terapiju, predstavljaju rizičnu populacionu grupu za razvoj komplikacija povezanih sa gripom, teži klinički tok i lošije ishode osnovne bolesti. Zbog toga se osobe sa hroničnim bolestima smatraju prioritetnom populacijom za imunizaciju protiv gripa. Imunizacija predstavlja ključnu strategiju za sprečavanje gripa, kako u pogledu obezbeđivanja imuniteta, tako i u pogledu troškova zdravstvene zaštite. Na osnovu preporuka Svetske zdravstvene organizacije (SZO), odgovarajući obuhvat imunizacijom protiv sezonskog gripa među osobama sa hroničnim bolestima predstavlja $75 \%$. Međutim, malo zemalja dostiže ovaj prag obuhvata. Razumevanje prediktivnih faktora vakcinacije na različitim nivoima pružanja zdravstvene zaštite (kao što su pojedinci, zdravstveni radnici, zdravstvena politika) od suštinskog je značaja za obezbeđivanje adekvatnog imuniteta i postizanje preporučenog nivoa obuhvata vakcinacijom. U ovom mini preglednom radu sumirali smo naučne dokaze o obuhvatu vakcinacijom protiv sezonskog gripa i faktorima povezanim sa imunizacijom protiv gripa kod osoba sa hroničnim bolestima u celini, kao i kod određenih bolesti poput kardiovaskularnih i plućnih, dijabetesa i malignih bolesti. Na osnovu pregledanih naučnih radova, utvrdili smo širok spektar faktora povezanih sa imunizacijom protiv gripa kod osoba sa hroničnim bolestima. Iako raznoliki, ovi faktori se mogu sistematizovati u 4 različite grupe, a to su:

Ključne reči:

grip,

imunizacija, hronične bolesti, prediktori sociodemografske karakteristike, individualni stavovi i verovanja, ponašanja koja promovišu zdravlje i faktori povezani sa zdravstvenim sistemom. Potrebno je uložiti dalje napore da bi se poboljšao obuhvat vakcinacijom protiv sezonskog gripa kod osoba sa hroničnim bolestima. Strategija imunizacije treba da uključi zdravstveni sistem i širu zajednicu kako bi se podržale osobe sa hroničnim bolestima da se kontinuirano vakcinišu protiv gripa.

\section{Introduction}

Seasonal influenza is an acute infection of the respiratory tract usually caused by influenza viruses type A or type B. Influenza virus type A is more common than type $\mathrm{B}$, as it is found in both humans and animals. This type of virus has the potential to induce moderate-to-severe forms of influenza (1). The infection mainly affects the upper respiratory organs, but can involve other organ systems, such as the cardiovascular, nervous or muscular.

The virus is predominantly transmitted through droplet spread, although transmission is also reported via freshly contaminated hands and inanimate objects (2). In recent decades, influenza typically caused epidemics every 1 to 4 years with varying degrees of intensity. The epidemic patterns are based on the antigenic features of the influenza virus, its infectious potential and susceptibility at the population level (3). These characteristics represent major factors associated with influenza-related morbidity and mortality. Bearing in mind that around $5-15 \%$ of the global population catches influenza viruses each year (4), new antigenic variants of the influenza virus type $A$ emerge every 3-5 years, while the new antigen variants of type $B$ viruses appear less frequently.

Annually, at a global level, 3 to 5 million people present severe clinical forms of seasonal influenza and up to 650000 people die of influenza-related complications (1). From a public health standpoint, it is essential to define risk groups that are more likely to have poorer outcomes of influneza, and for whom vaccination is highly recommended. This strategy leads to the reduction of influenza-related mortality, ambulatory visits and hospitalizations as well as financial burden of the health care system.

People with chronic diseases, such as cardiovascular, pulmonary, renal, hepatic, neurologic, hematologic, metabolic diseases or those reciveing immunosuppressive therapy, represent a high-risk population group for the development of influenza-related complications, more severe clinical course and poorer health-related outcomes (5). In fact, the number of hospital admissions and more severe outcomes among people who have chronic diseases is two times higher than that among people free from chronic diseases (5). Because of this, people with chronic diseases are of high priority to receive the seasonal influenza vaccine, in order to reduce potential premature mortality associated with complications of influenza or underlying health status $(6,7)$.

\section{Immunization against seasonal influenza}

Immunization represents key strategy to prevent seasonal influenza, both in terms of effectiveness and health care costs. While prevention of the infection is the target goal of the immunization program, it is still possible to catch the influenza virus after having received the vaccine. However, the clinical course of influenza is milder in people who had previously received the vaccine. The effectiveness of the influenza vaccine changes from season to season, depending on the individual 
characteristics (such as age or comorbidities) and the degree of antigenic overlap of the circulating influenza viruses with those included in the vaccine (8).

In the influenza season 2020/2021, most of the available influenza vaccines are quadrivalent i.e. they contain two type A viruses and two type B viruses. According to the Centers of Disease Control and Prevention (CDC), three influenza vaccines are being recommended: inactivated vaccine, recombinant vaccine and live attenuated vaccine (9). Inactivated and recombinant vaccines are applied intramuscularly, while live attenuated vaccine is applied intranasally. Live attenuated vaccine is not administered to pregnant women and people who have immunodeficiency (9). People who have chronic diseases typically receive inactivated influenza vaccine.

Based on the World Health Organization (WHO) recommendations, adequate seasonal influenza immunization coverage among people with chronic diseases is set at $75 \%(10)$. However, few countries were able to achieve this threshold (11). Overall, the vaccination coverage among people with chronic diseases is higher than that in the general population (12). A cross-sectional study from Greece found that the highest vaccination coverage in people with chronic diseases who presented at primary health care facility was detected among people with chronic kidney disease (55.6\%) and pulmonary disorders (53.9\%) (13). Lower coverage was detected among people with cardiovascular disorders (43.7\%), diabetes and malignant tumors $(40.6 \%)$ and neurological disorders (33.3\%) (13).

Understanding predictive factors of vaccination, at different levels of health care delivery (such as individual, health care providers, health policy), is essential to secure long-term acceptance of seasonal influenza immunization and achieve the recommneded level of vaccination coverage.

Seasonal influenza immunization and adults with chronic diseases overall

Studies focusing on the awareness about seasonal influenza immunization are important, because many people who have chronic diseases remain unaware of the existence of seasonal influenza immunization, as well as that this strategy can, in fact, prevent influenza-related morbidity and mortality. Specifically, a study from Southern Italy found that, of 700 adult persons with chronic diseases, $42.1 \%$ were immunized in the past season. However, only $64.7 \%$ of study respondents recognized that they were at risk of influenza-related complications and that immunization prevents the infection (14). People who were older, had more comorbidities, received information about the vaccine from doctors, perceived benefits of vaccination and had the intention to receive the vaccine in the next season, were more likely to have been vaccinated against seasonal influenza (14). Similar factors were observed among Greek people with chronic diseases (13). Specifically, people who were older, had more comorbidities and visited primary care physician multiple times in the past year, were more likely to receive the seasonal influenza vaccine (13).

Another consistent association of being older ( $\geq 65$ years) with seasonal influenza vaccination was observed in chronically ill people in Australia, where vaccination coverage of $47 \%$ was reported (15). Out of 868 pe ople with chronic diseases in France, who were followed over time, about one third (33.2\%) received the influenza vaccine (16). A further analysis suggested that in this cohort of people, immunization recommendation from a physician, visiting general practitioner, positive attitude about the usefulness of the vaccine and knowledge about seasonal influenza as a serious disease were associated with vaccine acceptance (16).

In a German population-based study of 1519 people with chronic diseases, vaccination coverage among adults aged $<60$ years was around $24 \%$, while among older adults, the coverage was about $50 \%$ (17). Factors contributing to seasonal influenza vaccination were being female, perceiving influenza as serious disease with potential adverse effects, and perceiving vaccination as an effective prevention. In addition to these, being older, having poor self-reported health and receiving advice from a physician were associated with influenza immunization in older adults with chronic diseases (17). A study of 8 337 people with chronic diseases who live in the Spanish capital Madrid reported the immunization coverage of $23.5 \%$ (18). People who were older, of Spanish nationality, not smoking and having lower education were more likely to be immunized (18).

A study in the United States investigated the impact of societal norms on seasonal influenza vaccine acceptance among Black and White people with chronic diseases (19). Several key predictors of vaccination were identified, such as better knowledge about the vaccine, having received vaccination recommendations, access to health care, vaccine confidence and vaccine hesitancy. Further, previous influenza vaccination and belief that vaccination is beneficial increased the likelihood of vaccine acceptance. Also, significant differences between people of the two races were observed: White people with chronic diseases were more likely to receive seasonal influenza vaccine compared to Black people with chronic diseases; Whites were also observed to be in a better socio-economic position, had more access to health care services, knew more about vaccination recommendations and had stronger positive attitudes about vaccination (19).

In health psychology, a number of authors used the Health Belief Model to approach the problem of in fluenza vaccine acceptance among people with chronic diseases. A recent systematic review of studies using this approach found that people who regard seasonal influenza immunization as beneficial, who do not perceive barriers to receive the shot and who have cues to take steps to receive the vaccine are more likely to be immunized (20). 
Seasonal influenza immunization and children with chronic diseases

Seasonal influenza immunization coverage in children with chronic diseases continues to be low, although there are variations in the coverage, depending on the type of chronic disease. Most countries in Europe have selective immunization programs, while in the United States, the seasonal influenza vaccine is offered to all children. The strongest predictive factor of influenza vaccine acceptance among children i.e. parents of children with chronic diseases, is having received a recommendation for vaccination from health care workers $(21,22)$. This factor remains associated with immunization when socio-demographic characteristics, type of chronic diseases and number of visits to physician are taken into account (21, 22 ). Doctor's recommendation was also observed as a predictor of vaccination in children who are chronically ill in the United States, highlighting that missed opportunities for vaccination during doctor's visits seem to be a key factor in low immunization coverage in this population group (23).

Seasonal influenza immunization and people with cardiovascular diseases

It is difficult to estimate the impact of seasonal influenza infection on people with ischemic heart diseases. A case-control study from Australia found that $10 \%$ of people who were hospitalized for acute myocardial infarction had influenza comorbidity at the time of admission (24). Further analysis showed that even though influenza vaccine did not prevent myocardial infarction, people who had previously received influenza vaccine had $45 \%$ less chance of developing acute myocardial infarction compared to those people who were not vaccinated (24). Another study showed that in people who previously had myocardial infarction, the vaccine coverage was $67.9 \%$ (25). Being older, male, not smoking, visiting a physician in the past month and controling blood pressure were associated with acceptance of the seasonal influenza vaccine (25).

A study of 229 people who had implantable cardiac defibrillator found that $78 \%$ of interviewees were vaccinated (26). Having stronger positive attitudes about vaccine safety was independently associated with seasonal influenza vaccination. Also, easier access to vaccination was observed as a predictor of vaccine acceptance (26).

Some data indicate that seasonal influenza vaccination among people with heart failure might decrease their all-cause morbidity and mortality (27). A global study of 8099 people with heart failure found remarkable variations in seasonal influenza vaccination coverage (28). For example, the highest coverage was observed in European countries (the Netherlands - 77.5\%, the United Kingdom - 77.2\%, Belgium - 67.5\%) and the lowest coverage was reported in Asian countries (2.6\%) (28). Overall, in the same population, people with heart failure who received seasonal influenza vaccine had 19\% lower risk of all-cause mortality compared to those that were not immunized (28). Advice from a cardiologist to receive the vaccine is probably the strongest contributing factor to acceptance of seasonal influenza immunization among people with heart failure (29).

In a cohort of 183 adult persons with congenital heart disease, less than one-half of individuals were immunized against influenza in the past season (30). Although numerous factors were identified to be associated with immunization in the univariate regression models, the adjusted model showed that only the perception of benefits of immunization and doctor's recommendation to receive the vaccine were, independently of other factors, associated with immunization compliance (30).

Seasonal influenza immunization and people with chronic respiratory diseases

A large health survey of 28113 people in Spain reported that the seasonal influenza vaccination coverage in adults with chronic respiratory diseases was $54.7 \%$ and in children with chronic respiratory diseases - 19.9\% (31). In the same study, among people aged 40 years and above who had chronic bronchitis, the vaccine coverage was approximately $63 \%$ (32). In this study, being older and male, not smoking, engaging in physical exercise and having other chronic diseases such as asthma or diabetes were associated with compliance to seasonal influenza immunization (32).

Using health psychology approach in adult people with chronic respiratory diseases in Hong Kong, such as the Health Belief Model, Cheung and Mak (33) found that recognizing one's susceptibility to influenza and its severity, as well as having psychological flexibility, were associated with the acceptance of seasonal influenza immunization.

The vaccination coverage among 15355 Spanish people aged 40 and above who had chronic obstructive pulmonary disease was $49.4 \%$ (34). The likelihood of vaccine acceptance in this cohort of patients increased with age. Also, characteristics such as being male, having poorer self-rated health, being non-smoker and seeing a physician in the past 4 weeks were associated with seasonal influenza vaccine uptake in this population group (34).

Catching the influenza virus can worsen the symtoms of asthma. The analysis of socio-demographic factors, life habits and use of health services among adults and children with asthma in Spain, suggested that 38\% of adults and $18.8 \%$ of children had received the vaccine (35). A similar vaccination coverage of $40 \%$ among adults with asthma was observed in the primary health care setting in the United Kingdom (36). More than one half of people with chronic asthma in Malta reported to have been immunized against flu (37), while in a sample of 167 people in a hospital-based clinic in New York City, the 
reported coverage was $71 \%$ (38). Overall, stronger beliefs in vaccine efficacy, feeling susceptible to the infection and its complications and receiving recommendation to accept vaccination were associated with seasonal influenza vaccine acceptance $(36,38)$.

Seasonal influenza immunization and people with diabetes

Diabetes is a major public health problem globally. A recommendation from a physician seems to have the pivotal role to accept seasonal vaccination in people with diabetes. Factors that predispose physicians to recommend influenza immunization to their patients who have diabetes are knowledge of national vaccination guidelines and policies, as well as their education about influenza and diabetes and belief in efficacy and safety of vaccines (39).

Poor self-rated health was predictive of seasonal influenza immunization in Australia (15). In a study of 1185 adults with diabetes from South Korea, $36.5 \%$ were immunized against influenza (40). Being more aware of immunization and receiving treatment for diabetes contributed to compliance with seasonal influenza vaccination (40). In people with diabetes in Spain, the coverage was somewhat higher (57\%) (41). Being male and older, having lung and heart diseases and having consultation with a physician in the past 2 weeks were associated with influenza immunization (41). In South Africa, more than one half of people with diabetes knew about the influenza vaccine, however, only about $28 \%$ were immunized (42). Receiving advice from a physician was a major determinant of vaccine acceptance (42).

The willingness of patients with type 2 diabetes mellitus in Southeast China to receive influenza vaccine was associated with their opinion that persons with diabetes were susceptible to the infection, knowledge that the vaccine is available and the fact that they were vaccinated against influenza in the past seasons (43).

Seasonal influenza immunization and people with malignant tumors

People who have verified hematological or solid malignant tumors and receive chemotherapy are at high risk of influenza-related complications. Systematic immunization could prevent further health decline and poor outcomes in these patients (44). Although it seems that children who have solid tumors have a more favourable immunity compared to children with haematological malignancies, vaccination recommendations for this population group correspond to those for adult patients $(45,46)$.

In cancer survivors in South Korea, vaccination coverage in older people was above the WHO recommended threshold of $75 \%$, but among younger adults it was as low as $26 \%$ (47). In Austria, more people with haematological malignancies were immunized against seasonal influenza than people with solid tumors (22\% vs. $13 \%)$ (48). Almost one-half of people with cancer in Israel accepted influenza immunization (49). A difference among 41346 adult White and Black cancer survivors in the United States was observed in the analysis of the Behavioral Risk Factor Surveillance System (50). Specifically, 65\% of Whites reported seasonal influenza vaccination in the past year vs. $50 \%$ of Blacks (50).

Factors associated with seasonal influenza immunization compliance among young adults in South Korea included older age, lower alcohol intake, rating own health as poor and shorter time since being diagnosed with cancer (47). In addition, receiving vaccination recommendation from a physician and previous influenza vaccinations increased the likelihood of vaccine acceptance $(48,49)$. In the United States, having higher education level, health insurance, specific primary care physician and visiting a physician in the past year were associated with seasonal influenza vaccine uptake among cancer survivors (50).

\section{Conclusion}

There is a wide spectrum of factors associated with immunization against seasonal influenza in people who have chronic diseases. Although diverse, these factors can be systematized into 4 distinctive groups (figure 1).

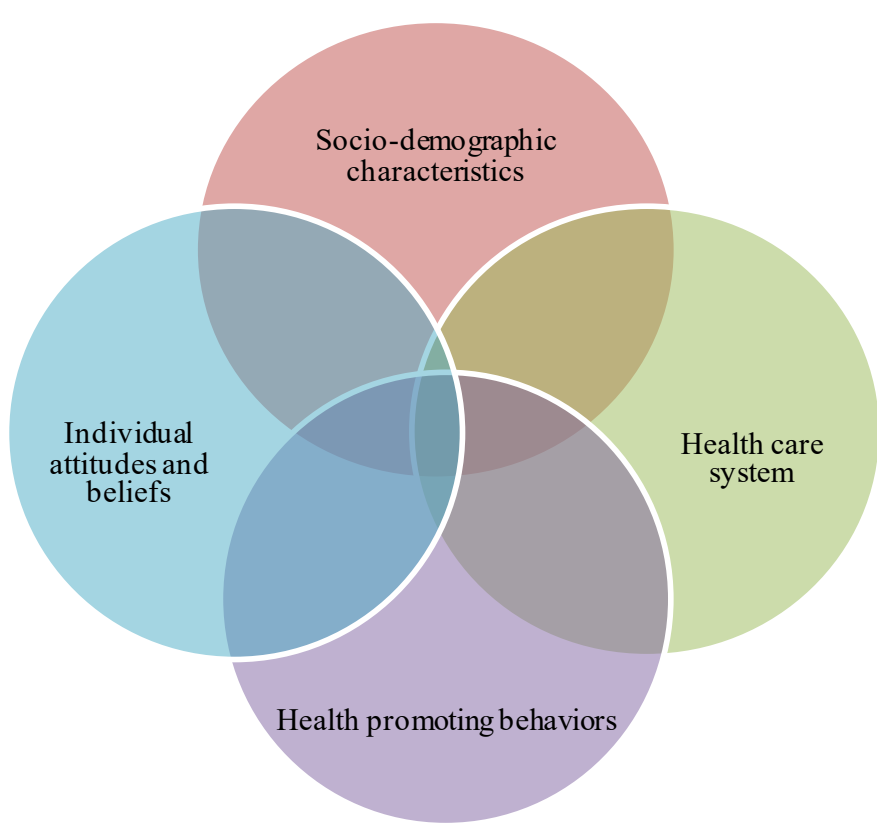

Figure 1. Classification of factors associated with influenza immunization in people with chronic diseases

First, several socio-demographic factors seem to be especially relevant for vaccine uptake. These include age, gender, level of education, socio-economic position depending on the health care system in which seasonal influenza immunization is not free of charge for people at high risk of influenza complications. Second, factors pertaining to the individual seem to play an important role in the decision to receive the vaccine. These factors comprise knowledge about seasonal influenza and influenza immunization, 
attitudes and beliefs about the vaccine and personal health. Third, health promoting behaviors, such as avoidance of smoking and alcohol intake, physical activity and adherence to the prescribed therapy could be considered as proxy of being conscious of own health. Fourth, factors related to the health care system include access to immunization, doctor's recommendation and previous influenza immunizations. They are part of the health system organization and planning. This is especially relevant, because doctor's recommendation seems to be one of the strongest determinants of vaccine uptake. Therefore, physicians in primary health care and other specialists who treat people with chronic diseases need to be aware that they have a key role in the process of seasonal influenza vaccine acceptance.

Based on the available empirical evidence, the seasonal influenza immunization coverage of people with chronic diseases is low and far from the WHO recommended target of $75 \%$. Further efforts are needed to improve the seasonal influenza vaccine coverage. The immunization strategy needs to include the health care system and the community to support people with chronic diseases to continously accept the influenza vaccine.

Literature

1. World Health Organization (WHO). Seasonal Influenza factsheet (Internet). 2018. Available from: http://www.who.int/mediacentre/factsheets/fs211/en/index.html

2. European Centre for Disease Prevention and Control. Seasonal influenza. Prevention Makes a Difference (Internet). Available from: https://www.ecdc.europa.eu/en/seasonal-influenza/facts/ key-messages

3. Moghadami M. A Narrative Review of Influenza: A Seasonal and Pandemic Disease. Iran J Med Sci. 2017; 42(1):2-13.

4. Petrova VN, Russell CA. The evolution of seasonal influenza viruses. Nat Rev Microbiol. 2018; 16:47-60.

5. Buchy $\mathrm{P}$, Badur $\mathrm{S}$. Who and when to vaccinate against influenza. Int J Infect Dis. 2020; 93:375-87.

6. Cheng Y, Cao X, Cao Z, Xu C, Sun L, Gao Y et al. Effects of influenza vaccination on the risk of cardiovascular and respiratory diseases and all-cause mortality. Ageing Res Rev. 2020; 62:101124.

7. European Center for Disease Control and Prevention. Risk groups for severe influenza (Internet). Available from: https://www. ecdc.europa.eu/en/seasonal-influenza/prevention-and-control/ vaccines/risk-groups

8. Arriola C, Garg S, Anderson EJ, Ryan PA, George A, Zansky SM, et al. Influenza Vaccination Modifies Disease Severity Among Community-dwelling Adults Hospitalized With Influenza. Clin Infect Dis. 2017; 65(8):1289-97.

9. Centers for Disease Control and Prevention. Seasonal Flu Shot (Internet). Available from: https://www.cdc.gov/flu/prevent/flushot.htm

10. World Health Organization. Seasonal vaccination policies and coverage in the European Region (Internet). Available from: https:// www.euro.who.int/en/health-topics/communicable-diseases/ influenza/vaccination/seasonal-vaccination-policies-and-coverage-in-the-european-region

11. Jorgensen P, Mereckieneb J, Cotterb S, Johansenc K, Tsolovac S, Browna C. How close are countries of the WHO European Region to achieving the goal of vaccinating $75 \%$ of key risk groups against influenza? Results from national surveys on seasonal influenza vaccination programmes, $2008 / 2009$ to $2014 / 2015$. Vaccine. 2018; 36(4):442-52.

12. Yan S, Wang Y, Zhu W, Zhang L, Gu H, Liu D et al. Barriers to influenza vaccination among different populations in Shanghai.
Hum Vaccin Immunother. 2020; 1-9.

13. Papaioannou A, Konstantinidi A-E, Primikiri E, Asimakopoulou F, Aravantinos D, Mavromichali Z. Influenza vaccination rate among high risk group patients in primary health care in Greece. Cent Eur J Public Health. 2020; 28(4):297-301.

14. Bertoldo G, Pesce A, Pepe A, Pelullo CP, Di Giuseppe G. Seasonal influenza: Knowledge, attitude and vaccine uptake among adults with chronic conditions in Italy. PLoS One. 2019; 14(5).

15. Dower J, Donald M, Begum N, Vlack S, Ozolins I. Patterns and determinants of influenza and pneumococcal immunisation among adults with chronic disease living in Queensland, Australia. Vaccine. 2011; 29:3031-7.

16. Casalino E, Ghazali A, Bouzid D, Antoniol S, Pereira L, Kenway P et al. Patient's behaviors and missed opportunities for vaccination against seasonal epidemic influenza and evaluation of their impact on patient's influenza vaccine uptake. PLoS One. 2018; 13(3).

17. Bodeker B, Remschmidt C, Schmich P, Wichmann O. Why are older adults and individuals with underlying chronic diseases in Germany not vaccinated against flu? A population-based study. BMC Public Health. 2015; 15:618.

18. Rodríguez-Rieiro C, Domínguez-Berjón MF, EstebanVasallodomínguez-Berjón MD, Cuadrado AR, Carrasco-Garrido P, Jiménez-García R. Coverage and predictors of influenza vaccine uptake among adults aged 16 to 59 years suffering from a chronic condition in Madrid, Spain. Hum Vaccin. 2011; 7(5):557-62.

19. Quinn SC, Jamison AM, Freimuth VS, An J, Hancock GR. Determinants of influenza vaccination among high-risk Black and White adults. Vaccine. 2017; 35(51):7154-9.

20. Borthwick C, O’Connor R, Kennedy L. Psychological predictors of seasonal influenza vaccination uptake among adults with a high-risk physical health condition: a systematic review. Psychol Health. 2021; 36(2):214-35.

21. Pandolfi E, Marino MG, Carloni E, Romano M, Gesualdo F, Borgia $\mathrm{P}$ et al. The effect of physician's recommendation on seasonal influenza immunization in children with chronic diseases. BMC Public Health. 2012; 12:984.

22. Pandolfi E, Carloni E, Marino MG, Ciofi degli Atti ML, Gesualdo F, Romano $\mathrm{M}$ et al. Immunization coverage and timeliness in Italian children with chronic diseases. Vaccine. 2012; 20(7):5172-8.

23. 23. Daley MF, Beaty BL, Barrow J, Pearson K, Crane LA, Berman $S$ et al. Missed opportunities for influenza vaccination in children with chronic medical conditions. Arch Pediatr Adolesc Med. 2005; 159:986-91.

24. Macintyre CR, Heywood AE, Kovoor P, Ridda I, Seale H, Tan T, et al. Ischaemic heart disease, influenza and influenza vaccination: a prospective case control study. Heart. 2013;99(24):1843-8.

25. 25. Jiménez-García $R$, Hernández-Barrera $V$, de Andres AL, Jimenez-Trujillo I, Esteban J, Gil A et al. Predictors of influenza vaccination uptake among adults with a history of heart attack. Hum Vaccin. 2010; 6(7):566-71.

26. Turner S, J de Souza R, Kumareswaran R, Singh SM. Barriers to Influenza Vaccination in Patients with Implantable Cardiac Defibrillators. Can J Cardiovasc Nurs. Summer 2015; 25(3):17-23.

27. Influenza infection and heart failure-vaccination may change heart failure prognosis? Kadoglou NPE, Bracke F, Simmers T, Tsiodras S, Parissis J. Heart Fail Rev. 2017; 22(3):329-36.

28. Vardeny O, Claggett B, Udell JA, Packer M, Zile M, Rouleau J et al. Influenza Vaccination in Patients With Chronic Heart Failure: The PARADIGM-HF Trial. JACC Heart Fail. 2016; 4(2):152-8.

29. Olanipekun T, Effoe VS, Olanipekun O, Igbinomwanhia E, KolaKehinde O, Fotzeu C et al. Factors influencing the uptake of influenza vaccination in African American patients with heart failure: Findings from a large urban public hospital. Heart Lung. 2020; 49(3):233-7.

30. Bare I, Crawford J, Pon K, Farida N, Dehghani P. Frequency and Consequences of Influenza Vaccination in Adults With Congenital Heart Disease. Am J Cardiol. 2018; 121(4):491-4.

31. López-de-Andrés A, Carrasco-Garrido P, Hernández-Barrera V, de Miguel AG, Jiménez-García R. Coverages and factors associated with influenza vaccination among subjects with chronic respiratory diseases in Spain. Eur J Public Health. 2008; 18(2):173-7. 
32. Jiménez-García R, Hernández-Barrera V, Carrasco-Garrido P, López de Andrés A, de Miguel AG. Predictors of influenza vaccination in adults with chronic bronchitis. Respir Med. 2009; 103(10):1518-25.

33. Cheung KW, Mak YM. Association between Psychological Flexibility and Health Beliefs in the Uptake of Influenza Vaccination among People with Chronic Respiratory Diseases in Hong Kong. Int J Environ Res Public Health. 2016; 13(2):155.

34. Santos-Sancho JM, Jimenez-Trujillo I, Hernández-Barrera V, López-de Andrés A, Carrasco-Garrido P, Ortega-Molina P et al. Influenza vaccination coverage and uptake predictors among Spanish adults suffering COPD. Hum Vaccin Immunother. 2012; 8(7):938-45.

35. Jiménez-García R, Hernández-Barrera V, Carrasco-Garrido $P$, Lopez de Andrés A, Miguel de Diez J, Gil de Miguel A. Coverage and predictors of adherence to influenza vaccination among Spanish children and adults with asthma. Infection. 2010; 38(1):52-7.

36. Keenan H, Campbell J, Evans PH. Influenza vaccination in patients with asthma: why is the uptake so low? Br J Gen Pract. 2007; 57(538):359-63.

37. Asciak R, Balzan M, Buttigieg J. Predictors of seasonal influenza vaccination in chronic asthma. Multidiscip Respir Med. 2013;8(1):68.

38. Lyn-Cook R, Halm EA, Wisnivesky JP. Determinants of adherence to influenza vaccination among inner-city adults with persistent asthma. Prim Care Respir J. 2007; 16(4):229-35.

39. Ye L, Chen J, Fang T, Cui J, Li H, Ma R et al. Determinants of healthcare workers' willingness to recommend the seasonal influenza vaccine to diabetic patients: A cross-sectional survey in Ningbo, China. Hum Vaccin Immunother. 2018; 14(12):2979-86.

40. Ko YM, Ko SH, Han K, Park Y-M, Choi JY, Kim SY et al. Importance of Awareness and Treatment for Diabetes in Influenza Vaccination Coverage of Diabetic Patients under 65 Years: A Population-Based Study. Diabetes Metab J. 2021; 45(1):55-66.

41. Jiménez-García R, Jimenez I, Garrido PC, Hernández-Barrera V, de Andres AL, del Barrio JL et al. Coverage and predictors of influenza vaccination among adults with diabetes in Spain. Diabetes Res Clin Pract. 2008; 79(3):510-7.

42. Olatunbosun OD, Esterhuizen TM, Wiysonge CS. A cross sectional survey to evaluate knowledge, attitudes and practices regarding seasonal influenza and influenza vaccination among diabetics in Pretoria, South Africa. Vaccine. 2017; 35(47):6375-86.

43. Feng W, Cui J, Li H. Determinants of Willingness of Patients with Type 2 Diabetes Mellitus to Receive the Seasonal Influenza Vaccine in Southeast China. Int J Environ Res Public Health. 2019; 16(12):2203

44. Alkan A, Karcı E, Yaşar A, Tuncay G, Köksoy EB, Ürün M et al. Vaccination in oncology practice and predictors. Support Care Cancer. 2017; 25(9):2677-82.

45. Kersun LS, Reilly AF, Coffin SE, Sullivan KE. Protecting Pediatric Oncology Patients From Influenza. Oncologist. 2013; 18(2):204-11.

46. Kersun LS, Reilly A, Coffin SE, Boyer J, Luning Prak ET, McDonald $\mathrm{K}$ et al. A prospective study of chemotherapy immunologic effects and predictors of humoral influenza vaccine responses in a pediatric oncology cohort. Influenza Other Respir Viruses. 2013; 7(6):1158-67.

47. Oh MG, Han MA, Yun NR, Park J, Ryu SY, Kim DM et al. A Population-Based, Nationwide Cross-Sectional Study on Influenza Vaccination Status among Cancer Survivors in Korea. Int J Environ Res Public Health. 2015; 12(8):10133-49.

48. Poeppl W, Lagler H, Raderer M, Sperr WR, Zielinski C, Herkner $\mathrm{H}$ et al. Influenza vaccination perception and coverage among patients with malignant disease. Vaccine. 2015; 33(14):1682-7.

49. Vinograd I, Baslo R, Eliakim-Raz N, Farbman L, Taha A, Sakhnini A et al. Factors associated with influenza vaccination among adult cancer patients: a case-control study. Clin Microbiol Infect. 2014; 20(9):899-905.

50. Stafford KA, Sorkin JD, Steinberger EK. Influenza vaccination among cancer survivors: disparities in prevalence between blacks and whites. J Cancer Surviv. 2013; 7(2):183-90. 